\title{
Influence of Integrated Nutrient Management on Soil Properties and Plant Nutrient Uptake in Maize
}

\author{
Krishnakhi Borah ${ }^{1 *}$ and Rinjumoni Dutta ${ }^{2}$ \\ Department of Agronomy, Assam Agricultural University, Jorhat-785013, India \\ *Corresponding author
}

\section{A B S T R A C T}

\begin{tabular}{|l|}
\hline K e y w o r d s \\
Integrated nutrient \\
management, \\
Plant nutrient \\
uptake, Maize \\
\hline Article Info \\
\hline $\begin{array}{l}\text { Accepted: } \\
\text { 20 November } 2018 \\
\text { Available Online: } \\
\text { 10 December } 2018\end{array}$ \\
\hline
\end{tabular}

Keywords

\section{Introduction}

Maize is one of the most versatile crops having wider adaptability under varied agroclimatic condition. Maize is the third most important food grain in India. Maize is considered as a promising crop for diversifying agriculture in upland areas of India. In Assam, maize is generally cultivated during kharif season under rainfed condition. But during kharif season rainfall causes difficulties in field preparation and seed germination is affected by excess of soil moisture. Moreover, nutrient loss and pest infestation are also more in kharif season which ultimately affect the yield of crop. But with the development of short duration varieties, it can be grown successfully in summer also. The unfavourable factors responsible for low yield during kharif do not exist in summer.

As a heavy feeder of nutrients, maize productivity is largely dependent on nutrient management. So, it needs fertile soil to produce a good yield. Chemical fertilizers are the primary source of plant nutrient. But soils which received plant nutrient only through chemical fertilizer are showing decreasing productivity. Excessive use of chemical fertilizer has been associated with decline in soil physical and chemical properties and crop 
yield (Kumar et al., 2016) and significant land problem such as degradation due to over exploitation of land, soil pollution caused by high application rates of fertilizer and pesticide application (Singh, 2000). Highest productivity of crops in sustainable manner without deteriorating the soil and other natural resources could be achieved only by applying appropriate combination of different organic manures and inorganic fertilizers (Chandrashekara et al., 2000). An integrated use of inorganic and biofertilizers should be opted for maximizing economic yield and to improve soil health (Syed Ismail et al., 2001). So it is important to identify the best type of available organic resources which can be used as fertilizers and their best combination with appropriate proportion of inorganic fertilizers.

\section{Materials and Methods}

A field experiment was conducted for the year 2016 in the summer season on maize at Instructional Cum Research Farm of Assam Agricultural University, Jorhat, India. The climate of the area is sub-tropical with hot summer and cold winter. The total amount of rainfall received during the period of experimentation was $1106.10 \mathrm{~mm}$ with a maximum average weekly rainfall of 258.6 $\mathrm{mm}$ on $16^{\text {th }}$ to $22^{\text {nd }}$ April, 2016. The weekly mean maximum temperature ranged from $33.5^{\circ} \mathrm{C}$ to $24.9^{\circ} \mathrm{C}$ and the weekly mean minimum temperature ranged from $26.1^{\circ} \mathrm{C}$ to $16.0^{\circ} \mathrm{C}$ during the crop growing period. The weekly average relative humidity during the morning hour ranged from 97 per cent to 88 per cent and in evening ranged from 91 per cent to 51 per cent. The two maize varieties (RCM-76 and DA-61-A developed from Barapani, Meghalaya) were sown on $18^{\text {th }}$ March (2016) at a spacing of $60 \mathrm{~cm} \times 20 \mathrm{~cm}$ and harvested by two picking at $24^{\text {th }}$ June and $4^{\text {th }}$ July (2016). Representative soil samples were collected prior to the experiment to study the initial soil physico-chemical properties of the experimental plot. The soil was sandy loam in texture, acidic in reaction $(\mathrm{pH} 4.94)$, medium in organic carbon $(0.72 \%)$, low in available $\mathrm{N}(159 \mathrm{~kg} / \mathrm{ha})$, low in available $\mathrm{P}_{2} \mathrm{O}_{5}$ $(23.78 \mathrm{~kg} / \mathrm{ha})$ and medium in $\mathrm{K}_{2} \mathrm{O}$ $(160.5 \mathrm{~kg} / \mathrm{ha})$. Experimental plots, $14.4 \mathrm{~m}^{2}$ $(4.8 \mathrm{~m} \times 3 \mathrm{~m})$ in size, were arranged in a split plot design and each treatment was carried out in triplicate. The treatments consisted of two varieties RCM-76 and DA-61-A in main plot and seven INM practices viz., $0 \mathrm{~kg}$ NPK/ha (I1), 60-40-40 kg NPK/ha (RDF) ( $\left.\mathrm{I}_{2}\right)$, $\mathrm{RDF}+$ Azospirillum+PSB $\left(\mathrm{I}_{3}\right), 50$ per cent $\mathrm{N}$ through chemical fertilizer+50 per cent replaced by vermicompost $\left(\mathrm{I}_{4}\right), 75$ per cent $\mathrm{N}$ through chemical fertilizer+25 per cent replaced by vermicompost $\left(\mathrm{I}_{5}\right), 50$ per cent $\mathrm{N}$ through chemical fertilizer+50 per cent replaced by enriched compost $\left(\mathrm{I}_{6}\right), 75$ per cent $\mathrm{N}$ through chemical fertilizer+25 per cent replaced by enriched compost $\left(\mathrm{I}_{7}\right)$ in sub plots. $\mathrm{N}$ was applied in 2 split doses. Soil texture was determined by Hydrometer Method (Bouyoucos, 1962). Glass electrode method (Jackson, 1973) was used to estimate the soil $\mathrm{pH}$. Soil organic carbon was determined by Wet digestion method (Walkey and Black, 1934). Available nitrogen, phosphorus and potassium was estimated by Kjeldahl method, Bray-I method and extraction with ammonium acetate and flame photometer method (Jackson, 1973) respectively. Intercultural operations and plant protection measures were taken as and when necessary. The yields were recorded on a whole-plot basis after discarding border plants. For chemical analysis, plant samples were oven dried at $65^{\circ} \mathrm{C}$ for 72 hours to a constant weight and ground to reduce the material to a fineness suitable size by using a mechanical grinder. The samples were stored in air-tight plastic containers. Samples were digested in diacid mixture of $\mathrm{H}_{2} \mathrm{SO}_{4}$ and $\mathrm{HClO}_{4}$ in the ratio of 9:1 for nutrient $\mathrm{N}$ estimation. $\mathrm{P}$ and $\mathrm{K}$ were estimated by Vanadomolybdate method and flame photometer method respectively. The nutrient 
uptake $(\mathrm{kg} / \mathrm{ha})$ by the crop was calculated by multiplying the cob yield per plot $(\mathrm{kg} / \mathrm{ha})$ with the nutrient content of the grain $(\%)$.

The data were analyzed statistically and the mean differences among the treatment means were evaluated by the split plot design at 5\% level of probability.

\section{Results and Discussion}

The yield of cob and stover was found higher in case of DA-61-A variety $(33.00 \mathrm{q} / \mathrm{ha}$ and $65.33 \mathrm{q} / \mathrm{ha}$ respectively) than the RCM-76 variety $(31.62 \mathrm{q} / \mathrm{ha}$ and $65.12 \mathrm{q} / \mathrm{ha}$ respectively). Among the INM practices the cob and stover yield was found highest in case of 50 percent $\mathrm{RD}$ of $\mathrm{N}$ through enriched compost +50 percent replaced by EC (39.83 $\mathrm{q} / \mathrm{ha}$ and $78.42 \mathrm{q} / \mathrm{ha}$ respectively). This is due to increased availability of nutrients, vitamins, hormones and minerals from enriched compost. During the time of preparation rock phosphate, Azospirillum and PSB were used for enriching the enriched compost. Rock phosphate contains apatite which is a mineral form of calcium and one of the most important functions of calcium is to enhance the $\mathrm{NO}_{3}{ }^{-}$ uptake. Azospirillum is a free living nitrogen fixing bacteria which promote plant growth. They colonize by adhesion, the root surface or the intercellular spaces of the host plant roots (McCully, 2001). Azospirillum promote plant growth by several mechanisms including $\mathrm{N}$ fixation, phytohormone production such as auxins, gibberellins, cytokinins, nitric oxide as signals of plant growth promotion.

PSB can solubilize the fixed soil P and applied phosphate resulting in higher crop yields. Phosphate (P) and potassium (K) solubilizing bacteria may enhance mineral uptake by plants through solubilizing insoluble $\mathrm{P}$ and releasing $\mathrm{K}$ from silicate in soil (Goldstein and Liu, 1987). Ultimately all these factors maintained a favourable soil physical, chemical and biological environment resulting better growth and development in yield attributes that ultimately had reflected in cob and stover yield of crop.

The nutrient uptake by maize as influenced by different varieties did not differ significantly. The higher uptake of $\mathrm{N}, \mathrm{P}, \mathrm{K}$ was found in case of DA-61-A variety than RCM-76. The nutrient uptake by maize as influenced by different sources of nutrients was found to be significant. The higher uptake was found in case of INM treatment as compared to control and RDF treatment. This might be due to the application of organic manure which enhanced the available nutrient status of soil and resulted in higher uptake of nutrient by the plants. The constant release of nitrogen from organic manure as a result of transformation process and increased mineralization of nitrogen resulted in higher uptake.

The higher uptake of potassium was probably due to constant release of potassium from total potassium in soil and also from applied manure, where as phosphorus uptake was higher due to reduced activity of phosphorus complexing agents, which leads to higher availability of phosphorus for uptake.

The increased nutrient uptake might be attributed to the favourable soil conditions and better root growth which might have enabled the crop to explore more volume of soil under different management practices. Significantly higher uptake of nutrients were recorded with the application of 50 per cent of RD of $\mathrm{N}$ through fertilizer +50 per cent $\mathrm{N}$ through enriched compost that favours soil microclimate which encourages the crop for more uptake of nutrients which in turn reflected in the crop yield (Table 1-3).

Availability of nutrient $\mathrm{N}, \mathrm{P}, \mathrm{K}$ in post-harvest soil was more in case of 75 percent RD of $\mathrm{N}$ through fertilizer +25 percent $\mathrm{N}$ through vermicompost $\left(\mathrm{I}_{5}\right)$ as compared to other treatment but they did not differ significantly. 
Table.1 Effect of varieties and INM practices on N, P and K content (\%) of maize grain and stover

\begin{tabular}{|c|c|c|c|c|c|c|}
\hline \multirow[t]{2}{*}{ TREATMENT } & \multicolumn{2}{|c|}{ N CONTENT $(\%)$} & \multicolumn{2}{|c|}{ P CONTENT $(\%)$} & \multicolumn{2}{|c|}{ K CONTENT $(\%)$} \\
\hline & GRAIN & STOVER & GRAIN & STOVER & GRAIN & STOVER \\
\hline \multicolumn{7}{|l|}{ VARIETY (V) } \\
\hline $\mathrm{V}_{1}=\mathrm{RCM}-76$ & 1.52 & 1.35 & 0.27 & 0.16 & 0.5 & 1.4 \\
\hline $\mathrm{V}_{2}=\mathrm{DA}-61-\mathrm{A}$ & 1.55 & 1.39 & 0.27 & 0.17 & 0.6 & 1.4 \\
\hline S.Ed. $( \pm)$ & 0.033 & 0.19 & 0.003 & 0.007 & 0.03 & 0.04 \\
\hline C.D (0.05) & NS & NS & NS & NS & NS & NS \\
\hline \multicolumn{7}{|l|}{ INTEGRATED NUTRIENT MANAGEMENT PRACTICES (I) } \\
\hline $\mathrm{I}_{1}=0 \mathrm{~kg} / \mathrm{ha}$ & 1.43 & 1.17 & 0.25 & 0.15 & 0.47 & 1.3 \\
\hline $\mathrm{I}_{2}=60-40-40 \mathrm{~kg} / \mathrm{ha}(\mathrm{RDF})$ & 1.51 & 1.31 & 0.26 & 0.17 & 0.51 & 1.4 \\
\hline $\mathrm{I}_{3}=\mathrm{RDF}+$ Azospirillum $+\mathrm{PSB}$ & 1.53 & 1.39 & 0.27 & 0.17 & 0.52 & 1.4 \\
\hline $\mathrm{I}_{4}=50 \% \mathrm{RD}$ of $\mathrm{N}$ through fertilizer $+50 \%$ replaced by $\mathrm{VC}$ & 1.54 & 1.40 & 0.28 & 0.17 & 0.54 & 1.5 \\
\hline $\mathrm{I}_{5}=75 \% \mathrm{RD}$ of $\mathrm{N}$ through fertilizer $+25 \%$ replaced by $\mathrm{VC}$ & 1.57 & 1.40 & 0.28 & 0.18 & 0.57 & 1.4 \\
\hline $\mathrm{I}_{6}=50 \% \mathrm{RD}$ of $\mathrm{N}$ through fertilizer $+50 \%$ replaced by $\mathrm{EC}$ & 1.61 & 1.48 & 0.31 & 0.18 & 0.60 & 1.5 \\
\hline $\mathrm{I}_{7}=75 \% \mathrm{RD}$ of $\mathrm{N}$ through fertilizer $+25 \%$ replaced by EC & 1.57 & 1.43 & 0.28 & 0.17 & 0.59 & 1.4 \\
\hline S.Ed. $( \pm)$ & 0.071 & 0.093 & 0.017 & 0.009 & 0.043 & 0.06 \\
\hline C.D. $(0.05)$ & NS & NS & NS & NS & NS & NS \\
\hline \multicolumn{7}{|l|}{ INTERACTION (V X I) } \\
\hline S.Ed. $( \pm)$ & 0.101 & 0.131 & 0.024 & 0.013 & 0.061 & 0.092 \\
\hline C.D. $(0.05)$ & NS & NS & NS & NS & NS & NS \\
\hline
\end{tabular}

Table.2 Effect of varieties and INM practices on N, P and K uptake ( $\mathrm{kg} / \mathrm{ha})$ of maize grain and stover

\begin{tabular}{|c|c|c|c|c|c|c|}
\hline \multirow[t]{2}{*}{ TREATMENT } & \multicolumn{2}{|c|}{ N UPTAKE (kg/ha) } & \multicolumn{2}{|c|}{$\begin{array}{l}\text { P UPTAKE } \\
(\mathrm{kg} / \mathrm{ha})\end{array}$} & \multicolumn{2}{|c|}{$\begin{array}{l}\text { K UPTAKE } \\
\text { (kg/ha) }\end{array}$} \\
\hline & GRAIN & STOVER & GRAIN & STOVER & GRAIN & STOVER \\
\hline \multicolumn{7}{|l|}{ VARIETY (V) } \\
\hline$V_{1}=$ RCM -76 & 39.69 & 77.40 & 8.8 & 10.8 & 17.1 & 92.3 \\
\hline $\mathrm{V}_{2}=\mathrm{DA}-61-\mathrm{A}$ & 39.93 & 79.09 & 9.2 & 11.5 & 18.4 & 94.0 \\
\hline S.Ed. $( \pm)$ & 3.75 & 3.39 & 0.3 & 0.3 & 1.1 & 5.1 \\
\hline C.D (0.05) & NS & NS & NS & NS & NS & NS \\
\hline $\begin{array}{lll}\text { INTEGRATED } & \text { NUTRIENT } & \text { MANAGEMENT } \\
\text { PRACTICES (I) } & & \end{array}$ & & & & & & \\
\hline $\mathrm{I}_{1}=0 \mathrm{~kg} / \mathrm{ha}$ & 21.48 & 51.16 & 4.4 & 6.8 & 8.3 & 57.4 \\
\hline $\mathrm{I}_{2}=60-40-40 \mathrm{~kg} / \mathrm{ha}(\mathrm{RDF})$ & 35.04 & 69.94 & 7.7 & 9.9 & 14.7 & 82.6 \\
\hline $\mathrm{I}_{3}=\mathrm{RDF}+$ Azospirillum $+\mathrm{PSB}$ & 35.82 & 73.46 & 8.1 & 10.6 & 16.0 & 90.0 \\
\hline $\mathrm{I}_{4}=50 \% \mathrm{RD}$ of $\mathrm{N}$ through fertilizer $+50 \%$ replaced by VC & 44.60 & 84.10 & 9.9 & 11.4 & 19.2 & 97.6 \\
\hline $\mathrm{I}_{5}=75 \% \mathrm{RD}$ of $\mathrm{N}$ through fertilizer $+25 \%$ replaced by $\mathrm{VC}$ & 45.26 & 87.47 & 10.2 & 12.2 & 20.6 & 101.5 \\
\hline $\mathrm{I}_{6}=50 \% \mathrm{RD}$ of $\mathrm{N}$ through fertilizer $+50 \%$ replaced by EC & 51.29 & 92.77 & 12.3 & 14.4 & 23.8 & 118.1 \\
\hline $\mathrm{I}_{7}=75 \% \mathrm{RD}$ of $\mathrm{N}$ through fertilizer $+25 \%$ replaced by EC & 45.15 & 88.82 & 10.2 & 12.8 & 21.7 & 104.9 \\
\hline S.Ed. $( \pm)$ & 2.74 & 6.11 & 0.8 & 0.8 & 1.6 & 6.9 \\
\hline C.D. $(0.05)$ & 4.66 & 10.45 & 1.3 & 1.4 & 2.8 & 11.8 \\
\hline \multicolumn{7}{|l|}{ INTERACTION (V X I) } \\
\hline S.Ed. $( \pm)$ & 3.874 & 8.638 & 1.063 & 1.150 & 2.224 & 9.774 \\
\hline C.D.(0.05) & NS & NS & NS & NS & NS & NS \\
\hline
\end{tabular}


Table.3 Effect of varieties and INM practices on available soil N, P, K (kg/ha), cob yield (q/ha) and stover yield (q/ha)

\begin{tabular}{|c|c|c|c|c|c|}
\hline TREATMENT & $\begin{array}{l}\text { Available } \\
\text { N (kg/ha) }\end{array}$ & $\begin{array}{c}\text { Available } \\
\mathbf{P}_{2} \mathbf{O}_{5} \\
\text { (kg/ha) }\end{array}$ & $\begin{array}{c}\text { Available } \\
\mathrm{K}_{2} \mathrm{O} \\
(\mathrm{kg} / \mathrm{ha})\end{array}$ & $\begin{array}{l}\text { Yield } \\
\text { (q/ha) }\end{array}$ & $\begin{array}{c}\text { Stover } \\
\text { yield } \\
\text { (q/ha) }\end{array}$ \\
\hline \multicolumn{6}{|l|}{ VARIETY (V) } \\
\hline $\mathrm{V}_{1}=\mathrm{RCM}-76$ & 154.35 & 22.84 & 152.71 & 31.62 & 65.12 \\
\hline$V_{2}=D A-61-A$ & 144.57 & 22.07 & 147.62 & 33.00 & 65.33 \\
\hline S.Ed. $( \pm)$ & 2.425 & 1.608 & 13.531 & 1.540 & 1.820 \\
\hline C.D (0.05) & NS & NS & NS & NS & NS \\
\hline \multicolumn{6}{|l|}{$\begin{array}{lll}\text { INTEGRATED } & \text { NUTRIENT } & \text { MANAGEMENT } \\
\text { PRACTICES (I) } & & \\
\end{array}$} \\
\hline$I_{1}=0 \mathrm{~kg} / \mathrm{ha}$ & 140.00 & 20.00 & 131.67 & 17.50 & 43.83 \\
\hline$I_{2}=60-40-40 \mathrm{~kg} / \mathrm{ha}(\mathrm{RDF})$ & 145.48 & 21.13 & 150.33 & 29.50 & 59.92 \\
\hline $\mathrm{I}_{3}=\mathrm{RDF}+$ Azospirillum $+\mathrm{PSB}$ & 146.67 & 21.68 & 151.67 & 30.50 & 63.67 \\
\hline $\begin{array}{l}I_{4}=50 \% \text { RD of } N \text { through fertilizer }+50 \% \text { replaced } \\
\text { by VC }\end{array}$ & 153.74 & 23.23 & 154.67 & 35.50 & 66.48 \\
\hline $\begin{array}{l}I_{5}=75 \% \text { RD of } N \text { through fertilizer }+25 \% \text { replaced } \\
\text { by VC }\end{array}$ & 156.25 & 24.26 & 157.00 & 36.17 & 71.12 \\
\hline $\begin{array}{l}I_{6}=50 \% \mathrm{RD} \text { of } \mathrm{N} \text { through fertilizer }+\mathbf{5 0 \%} \text { replaced } \\
\text { by } \mathrm{EC}\end{array}$ & 151.64 & 22.64 & 152.50 & 39.83 & 78.42 \\
\hline $\begin{array}{l}I_{7}=75 \% \mathrm{RD} \text { of } \mathrm{N} \text { through fertilizer }+25 \% \text { replaced } \\
\text { by EC }\end{array}$ & 152.45 & 24.25 & 153.33 & 37.17 & 73.17 \\
\hline S.Ed.( \pm$)$ & 7.753 & 1.658 & 11.109 & 1.394 & 4.668 \\
\hline C.D. (0.05) & NS & NS & NS & 2.384 & 7.982 \\
\hline \multicolumn{6}{|l|}{ INTERACTION (V X I) } \\
\hline S.Ed.( \pm$)$ & 10.964 & 2.344 & 15.71 & 1.972 & 1.829 \\
\hline C.D.(0.05) & NS & NS & NS & NS & NS \\
\hline
\end{tabular}

In conclusion, INM impoverished the soil characteristics as compared to control and RDF treatment. So to increase uptake of nutrient and effective management of soil properties, 50 per cent of RD of $\mathrm{N}$ through fertilizer +50 per cent $\mathrm{N}$ through enriched compost with DA-61-A variety is the best combination for cultivation of summer maize which will improve the yield of crop and also soil properties for succeeding crop.

\section{References}

Bouyoucos, G. J. (1962). Hydrometer method improvement for making particle size analysis of soils. Agronomy Journal 54: 179-186.

Chandrashekara, C.P., Harlapur, S.I., Muralikrishna, S. and Girijesh, G.K. (2000). Response of maize to organic manure with inorganic fertilizers. Karnataka J. Agric. Sci. 13: 144-146.

Jackson, M. L. 1973. Soil chemical analysis. Prentice Hall of India Pvt. Ltd., New Delhi.

Kumar, S., Kumar, A., Singh, J and Kumar, P. (2016). Growth indices and nutrient uptake of fodder maize (Zea mays L.) as influenced by integrated nutrient Management. Forage Res. 42(2): 119- 
123.

McCully, M.E. (2001). Niches for bacterial endophytes in crop plants: a plant biologist's review. Aust. J. plant Physiol. 28: 983-990.

Singh, R.B. (2000). Environmental consequences of agricultural development: a case study from the green revolution state of Haryana. Agric. Ecosyst. Env. 82(3): 97-103.

Syed Ismail, A.P.B., Shinde, G.G. and
Deshmukh, A.S. (2001). Impact of FYM and fertilizer nitrogen on yield and soil properties of sorghum grown on Vertisol. Int. Sorghum Millets Newsl. 42: 29-31.

Walkley, A. and Black, C. A. 1934. An experimentation of the method for determination of soil organic matter and proposed modification of the chromic acid titration method. Soil science 37: 29-39.

\section{How to cite this article:}

Krishnakhi Borah and Rinjumoni Dutta. 2018. Influence of Integrated Nutrient Management on Soil Properties and Plant Nutrient Uptake in Maize. Int.J.Curr.Microbiol.App.Sci. 7(12): 26512656. doi: https://doi.org/10.20546/ijcmas.2018.712.301 